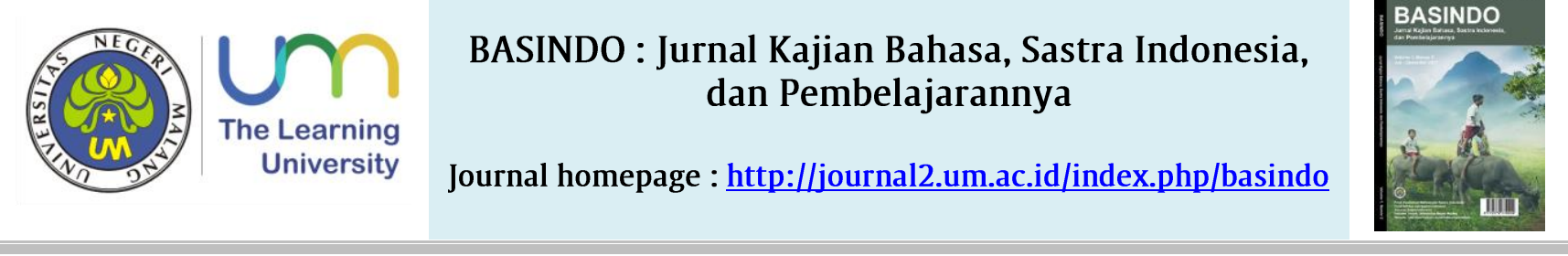

\title{
MENGNTENSIFKAN PERAN PENDIDIKAN SASTRA UNTUK MEMBAGUN KARAKTER SISWA
}

\author{
Jumadi \\ Program Studi Pendidikan Bahasa dan Sastra Indonesia, FKIP, Universitas Lambung Mangkurat
}

\section{A R T I K E L}

Kata Kunci:

peran pendidikan

membangun karakter

satra

\begin{abstract}
A B S T R A K
Berbagai peristiwa yang mengindikasikan terjadinya kemerosotan moral seolah menjadi hal yang biasa. Kita bisa menyaksikan gejala itu hamper pada semua situs kehidupan kita. Gejala itu tentu tidak bisa dibiarkan terus berlangsung. Perlu dilakukan reformasi pendidikan yang memberi perhatian lebih pada upaya memperbaiki karakter, terutama para siswa sehingga mereka tumbuh menjadi orang yang tahu kebenaran, mencintai kebenaran, dan melakukan kebenaran. Terkait dengan upaya itu, pendidikan sastra mempunyai peran sangat strategis. Di dalam sastra terungkap unsur-unsur moral yang dapat digunakan untuk membangun karakter siswa. Peran pendidikan sastra akan berhasil membangun karakter siswa bila pendidikan sastra dirancang dengan baik, baik menyangkut materi pendidikan, proses pendidikan, maupun system evaluasi yang digunakan. Materi pendidikan sastra hendaknya kontekstual; proses pendidikannya menggunakan model respon; dan sistem evaluasinya menekankan pada proses daripada hasil.
\end{abstract}

(C) 2017 BASINDO Journal. All rights reserved

\section{PENDAHULUAN}

Akhir-akhir ini kita dihadapkan kepada suatu gejala yang semakin sulit membedakan antara fiksi dan nonfiksi. Dalam dunia fiksi, sering terjadi absurditas sehingga seorang tokoh yang jatuh dari atas apartemen ke jalan yang aspalnya lagi meleleh bisa saja tidak tewas, tetapi justru melampiaskan libido seksual dengan lawan jenisnya. Dalam dunia fiksi, kehidupan memberi ruang bagi pengarang untuk merepresentasikan "keliaran" imajinya. Oleh karena itu, koherensi logika dari peristiwa tersebut bisa diterima manakala kita menempatkanya pada konteks eksistensi manusia sebagai aku, makhluk yang berkehendak, bukan sekadar onggokan darah dan daging. Sebaliknya, dalam dunia nonfiksi, koherensi logika kehidupan diselaraskan dengan kodrat manusia sebagai makhluk individu dan makhuk sosial. Sebagai makhluk individu, dia pasti punya rasa lapar, tetapi tidak mungkin dia menelan tiang listrik. Sebagai makhluk sosial, dia tentu mempunyai hasrat untuk berinteraksi dengan orang lain. Jika kita sepakat dengan pendapat Sigmun Freud, realisasi hasrat itu perlu diselaraskan dengan kehendak "lembaga moral" yang ada pada kita yang bernama superego. Karena memiliki lembanga moral inilah, manusia bisa mencegah dorong ego untuk berbuat jahat. Dia akan didera rasa bersalah manakala melanggar norma agama, norma hukum, dan norma sosial.

Batas logika dunia fiksi dan nonfiksi tersebut tampaknya semakin kabur sehingga sulit dibedakan. Dalam dunia nonfiksi, aparat hukum seharusnya berada pada garda paling depan dalam memberikan contoh mematuhi hukum. Namun, apa yang terjadi, tidak sedikit aparat kepolisian, aparat kejaksaan, aparat kehakiman, bahkan ketua mahkamah konstitusi mengkhianati amanah jabatannya dengan melakukan korupsi. Para guru dan kepala sekolah selalu mendidik siswanya menjadi orang jujur, tetapi manakala ujian akhir tiba, ada diantara mereka yang menjadi perancang dan pelaksana pembocoran soal dan jawaban kepada para siswa yang sehari-hari mereka didik menjadi manusia jujur. Seorang anak tentu harus berbakti kepada ibunya yang telah dengan susah payah mengandung dan membesarkanya. Namun, dengan sadisnya ada seorang anak malah menghabisi ibunya karena persoalan warisan. Halaman ini tentunya masih bisa diperpanjang dengan berbagai realitas yang menunjukkan bahwa absurditas telah merambah pada semua situs kehidupan kita. Sekarang yang menjadi pertanyaan, siapakah yang harus mengambil tanggung jawab agar realitas sosial kehidupan kita tidak berkembang menjadi peradaban yang dipenuhi absurditas?

\footnotetext{
${ }^{*}$ Corresponding author.

E-mail addresses: jum_swot@yahoo.com (Jumadi)
}

2579-3799/ @ 2017 BASINDO Journal. All rights reserved. This is an open access article under the CC BY license (http://creativecommons.org/licenses/BY/4.0/).

31 | BASINDO : Jurnal Kajian Bahasa, Sastra Indonesia, dan Pembelajarannya 
Untuk menjawab pertanyaan itu, kita mungkin bisa belajar dari Cina, sebuah negara dengan jumlah penduduk terbanyak di dunia, tapi sukses membangun karakter warganya yang sekaligus mengagumkan dalam membangun pertumbuhan ekonominya. Adalah Deng Xioping, seorang peminpin besar Cina, pada tahun 1985 secara tegas menekankan pentingnya reformasi pendidikan untuk membangun karakter bangsa. Dia menyatakan, "Troughout the reform of the education system, it is imperative to bear in mind that reform is for the fundamental purpose of turning every citizen, into a man or women of character and cultivating more constructive members of sociaty." Pendidikan karakter di Cina berorientasi pada mengukir akhlak mulia melalui proses knowing the good, loving the good, dan acting the good sehingga akhlak mulia bisa terukir menjadi habit of mind, heart, and hands (lihat Komalasari, 2013: 421).

Dengan cara apa karakter seseorang bisa dibangun? Menurut hemat penulis banyak hal yang bisa kita lakukan. Tulisan ini menyajikan gagasan mengintensifkan pendidikan sastra untuk membangun karakter siswa. Secara bertuturturut dalam tulisan ini dibahas: (a) apa itu karakter dan unsur-unsur moral pembangun karakter, (b) mengapa perlu mengintensifkan pendidikan sastra, dan (c) pendidikan sastra yang bagaimana yang bisa membangun karakter siswa?

\section{Apa itu Karakter dan Unsur-unsur Moral Pembangun Karakter}

Banyak pakar yang mencoba memberikan pengertian karakter. Menurut bapak pendidikan karakter Amerika Serikat, Lickona (1991:51), karakter adalah a reliable inner disposition to respond situation in good away. Dari pengertian ini tampak bahwa karakter merupakan pembawaan yang agung yang digunakan untuk merespon situasi dengan cara yang baik.

Sebagai pembawaan yang agung, karakter tidak begitu saja dimiliki oleh seseorang. Karakter terbentuk dari proses internalisasi terhadap unsur-unsur moral. Menurut Lickona (1991:53-62) dibangun oleh sejumlah moral. Paling tidak ada tiga unsur pembangun karakter yang baik, yaitu pengetahuan tentang moral (moral kwnowing), perasaan tentang moral (moral feeling), dan perbuatan yang bermoral (moral action). Untuk memperjelas paparan ini, marilah kita perhatikan gambar berikut ini.

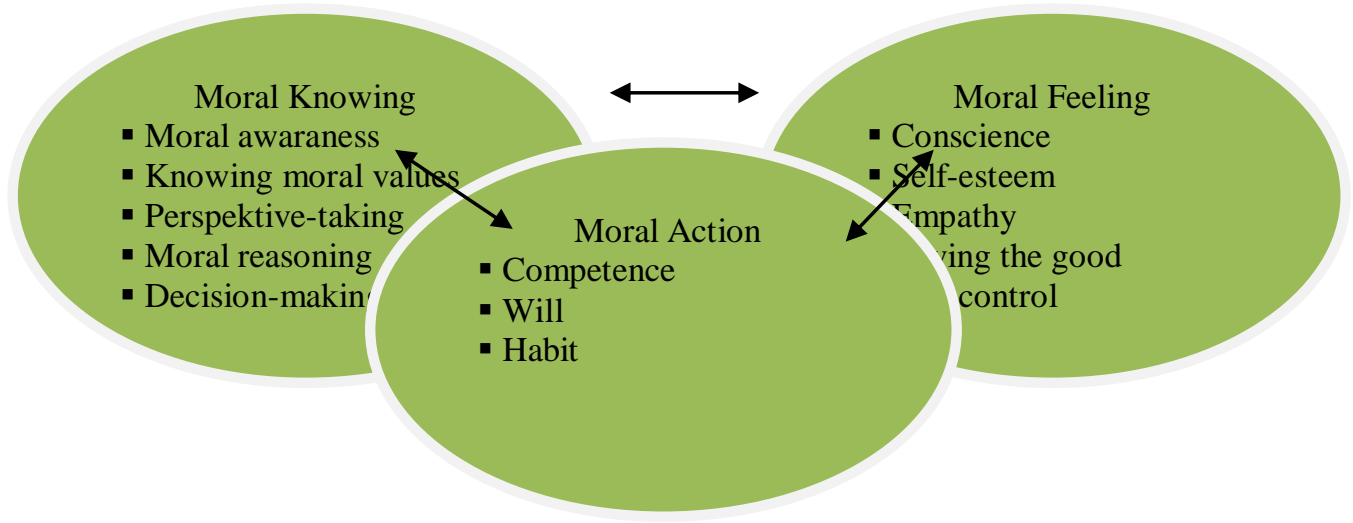

Gambar 1: Unsur-unsur Karakter yang Baik

Dari Gambar 1 tampak bahwa ketiga unsur karakter yang baik tersebut memiliki subunsur yang tidak dapat dipisahkan dengan subunsur yang lain. Disamping itu, pemisahan ketiga unsur karakter tersebut mengisyaratkan terjadinya tahapan proses internalisasi nilai moral itu sebelum benar-benar menjadi amalan dalam kehidupan seharihari. Pada awalnya siswa perlu memiliki pengetahuan tentang moral (moral knowing) dengan berbagai unsurnya, mulai dari kesadaran moral (moral awareness) hingga pengetahuan diri (self-knowledge). Pengetahuan moral tersebut akan memberikan pemahaman tentang karakteristik masing-masing moral. Pengetahuan tentang moral tersebut merupakan prasyarat bagi terbentuknya perasaan moral (moral feeling) dengan berbagai unsurnya, mulai dari kepemilikan hati nurani (conscience) hingga kerendahan hati (humility) pada diri siswa. Pada ujung semua itu, setelah terjadi proses pemahaman dan perasaan moral, akan terjadi tindakan moral (moral action) dalam kehidupan nyata. Ada tiga unsur penopang terjadinya tindakan moral, yakni adanya kemampuan (competence) untuk melaksanakan, adanya keinginan (will) untuk melaksanakan, dan adanya tindakan nyata yang terus-menerus sehingga nilai moral menjadi kebiasaan (habit) dalam kehidupan sehari-hari.

Dalam perspektif yang sedikit berbeda, Michele Borba (2001:6-7), membagi tujuh kecerdasan moral dalam membangun karakter siswa. Kebaikan esensial dari ketujuh kecerdasan moral yang perlu dikembangkan adalah empati (empaty), hati nurani (conscience), kontrol diri (self-control), rasa hormat (respect), kebaikan hati (kindness), toleran (tolerant), dan kejujuran (fairness).

Usaha memahami apa yang dirasakan orang lain disebut dengan empati. Semua itu merupakan kebaikan yang menjadikan siswa lebih sensitif terhadap keperluan dan perasaan orang lain. Hati nurani adalah sebuah suara dari dalam diri siswa yang amat kuat yang membantunya membedakan antara yang salah dengan yang benar. Kebaikan ini mempertahankan siswa menolak kekuatan yang menentang kebaikan dan memungkinkannya berbuat kebaikan dalam berbagai wujud godaan. Kontrol diri membantu siswa melatih kembali dorongan-dorongan dan pikiran sebelum dia melakukan tindakan yang memungkinkan membuat pilihan yang kurang hati-hati yang berpotensi mendatangkan bahaya. Rasa hormat memberikan harapan kepada siswa untuk memperlakukan siswa yang lain dengan perhatian sebab dia menghargainya sebagai manfaat. Kebaikan hati membantu siswa menunjukkan perhatiannya tentang kesejahteraan dan berbagi rasa sejahtera itu kepada orang lain. Dengan mengembangkan kebaikan ini, siswa akan menjadi kurang mementingkan diri sendiri dan lebih simpatik, dan dia akan lebih memahami bahwa memperlakukan orang lain secara baik merupakan perbuatan yang mudah untuk dilakukan. Toleran membantu 
siswa untuk menghargai kualitas siswa yang lain, selalu terbuka terhadap keyakinan dan perspektif yang baru, dan menghormati yang lain tanpa memperhatikan suku, jenis kelamin, penampilan, budaya, keyakinan, kemampuan, dan orientasi seksual. Kejujuran membimbing siswa untuk memperlakukan orang lain dengan baik budi, tidak berat sebelah, dan dengan cara yang tepat sehingga dia akan lebih mungkin menjalankan hukum, saling memberi/menerima, dan mendengarkan secara terbuka untuk semua sisi sebelum mengambil keputusan.

Unsur-unsur moral sebagaimana dipaparkan di atas jika dipakai sebagai pedoman dalam bertindak akan membangun karakter seseorang. Dalam proses pendidikan, karakter mana yang perlu ditanamkan kepada diri siswa? Terkait dengan hal ini, para pakar juga mempunyai pandangan yang beragam. Keragaman itu karena perbedaan orientasi dan sudut pandang sehingga dalam implementasinya bisa saja saling melengkapi. Megawangi (dalam Sauri, 2013:285) menyebutkan 9 pilar karakter yang perlu diinternalisasikan kepada siswa, yaitu (a) cinta kepada Tuhan dan kebenaran, (b) bertanggung jawab dan disiplin, (c) amanah, (d) hormat dan santun, (e) kasih sayang, peduli, dan kerja sama, (f) percaya diri, kreatif, dan pantang menyerah, (g) keadilan dan kepemimpinan, (h) baik dan rendah hati, dan (i) toleran dan cinta damai. Sementara itu, Hasan dkk. (2010:8) menyebutkan 18 karakter yang perlu diinternalisasikan, yaitu (a) religius, (b) jujur, (c) toleransi, (d) disiplin, (e) kerja keras, (f) kreatif, (g) mandiri, (h) demokratis, (i) rasa ingin tahu, (j) semangat kebangsaan, ( $\mathrm{k}$ ) cinta tanah air, (l) menghargai prestasi, (m) bersahabat/komunikatif, (n) cinta damai, (o) gemar membaca, (p) peduli lingkungan, (q) peduli sosial, dan (r) tanggung jawab.

\section{Mengapa Perlu Mengintensifkan Pendidikan Sastra}

Untuk menghindari terjadinya kemerosotan moral yang semakin parah dan berkelanjutan, kita perlu membangun karakter siswa sebagai generasi emas yang akan menggantikan peran generasi sekarang di masa yang akan datang. Dengan belajar dari negeri Cina, kita perlu segera mengintensifkan peran pendidikan untuk membangun karakter siswa. Pendidikan memberikan ruang bagi pengajaran etika moral dan segenap aturan luhur yang membimbing siswa mencapai humanisasi. Melalui proses pendidikan, siswa menjadi terbimbing, tercerahkan, sementara tabir ketidaktahuannya terbuka lebar-lebar sehingga mereka mampu mengikis bahkan meniadakan aspekaspek yang mendorong ke arah dehumanisasi.

Sekarang yang menjadi pertanyaan, mungkinkah pendidikan sastra berperan seperti itu? Jawabannya sangat mungkin sebab dilihat dari substansi yang akan disampaikan kepada siswa, sastra mengandung unsur-unsur karakter secara melimpah. Boulton (dalam Aminuddin, 1984:9) menyatakan bahwa cipta sastra selain menyajikan nilai-nilai keindahan serta paparan peristiwa yang mampu memberikan kepuasan batin pembacanya, juga mengandung pandangan yang berhubungan dengan renungan atau kontemplasi bati, baik berhubungan dengan masalah keagamaan, filsafat, politik, maupun berbagai macam problema yang berhubungan dengan kompleksitas kehidupan ini. Sastra hendaknya tidak hanya membuka mata bagi kekuarangan-kekuarangan di masyarakat, tetapi juga menunjukkan jalan ke luar.

Bagi nenek moyang kita, sastra amat berperan sebagai instrumen kehidupan. Oleh karena itu, sastra amat akrab dengan kehidupan mereka. Mereka memanfaatkan sastra sebagai salah satu sumber kebenaran, di samping sumber kebenaran agama, filsafat, dan ilmu. Nenek moyang kita telah memberi contoh amat baik. Misalnya, ketika akan menabur benih, menebang pohon, menakhlukkan binatang buas, atau memikat lawan jenis, mereka memanfaatkan sastra dalam bentuk mantra sebagai sarana berkominikasi dengan Sang Pencipta; ketika melakukan peminangan untuk meneruskan garis keturunan, mereka memanfaatkan pantun sebagai sarana komunikasi berbudi; ketika akan menidurkan anak atau memberikan pendidikan, mereka bersastra dalam bentuk pantun. Berikut dikutipkan terjemahan penggalan dindang yang biasa dilantunkan ibu-ibu pada zaman dahulu di Kalimantan Selatan ketika menidurkan buah hatinya.

Tidur-tidur anakku tidur

Kutidurkan dalam ayunan

Lailaha ilallah

Muhammadur Rasulallah

Anakku pintar orang beriman

Matanya sangat mengantuk disuruh tidur

Tidur-tidur anakku tidur

Kutidurkan dalam ayunan

Lailaha ilallah

Muhammadur Rasulallah

Cepatlah tidur pejamkan mata

Kalau dewasa jadi ulama

(Marfuah, 2013:23).

Sekarang dindang yang dilantunkan oleh ibu-ibu di Kalimantan Selatan ketika menidurkan anaknya nyaris tak terdengar. Padahal, kalau dilihat dari isinya, dindang itu berisi doa dan harapan yang sarat dengan pendidikan karakter religius. Unsur-unsur pendidikan karakter sangat melipah dalam khazanah sastra lama kita, baik dalam pantun, fabel, mite, legenda, atau yang lain. Terkait dengan ini, penulis sepakat dengan Teuw (1982) yang menyatakan bahwa dalam sastra daerah di Indonesia terungkap kreativitas sastra yang luar biasa. Dalam hasil sastra itu manusia Indonesia 
berusaha untuk mewujudkan hakikat dirinya sedemikian rupa sehingga sampai sekarang pun, untuk manusia modern, ciptaan tersebut tetap mempunyai nilai dan fungsi -- asal dia bersedia berusaha merebut maknanya bagi dia sebagai manusia modern.

Dalam sastra Indonesia modern juga banyak terkandung unsur-unsur pendidikan karakter. Jika dimanfaatkan secara intensif dalam dunia pendidikan, kita bisa mencegah terjadinya penistaan agama, pertengkaran pelajar, penyerangan antarsuku, keserakahan, atau yang lain. Berikut ini contoh puisi yang dapat dimanfaatkan untuk membangun karakter cinta lingkungan.

\section{Surat untuk Abah}

Abah,

Aku rindu pucuk ulin dan rimbun hutan tarap

di belakang rumah kita

Bah,

salahkah

bila punai tak lagi menciap

enggang gunung kaku menari

dan embun tergugu di kegersangan ilalang

Di sini Bah!

Dara Dayak enggan menari

Dan lengking kekasihnya ditelan pabrik sepanjang

sungai

Ada yang terrenggut

Ada giris

Sesal

Ketika damai luruh bersama terjungkalnya meranti

tua

Bumi tergetar

Anak pinak satwa terburai

Ke mana kita pulang Bah!

Ketika kijang gunung sesat

Banteng tunggal kehilangan belukar

Ke mana kita?

Saat Mahakam kalap

dan gunung lipan terbungkuk bersimbah peluh,

Duh,

Aku rindu dara dayak bertelinga panjang

Aku rindu wangi rawa

Aku kangen hutan payau

Ingin aku Bah!

Memilih rotan saga

Mengecup embun belukar

Mencumbu ranting meranti yang tegar di

kesendirian

Bah,

Kealpaan menyiasati sorga kita

Sehingga debu dan arang kita wariskan

Untuk anak cucu kita

Kini yang dini!

Dengan kedua biji mata kita

Sanggupkah memupus harap

Sementara traktor bercumbu dengan ulin

Dan huma kita terkurung pencakar langit

Sanggupkah?

Mematut diri

Bercermin alam

Sementara mereka menuntut miliknya

Duh Abah!

Pulang sajalah kita

Rawa kehilangan wangi

Hutan terjengkal

Dan ranting kurus tak tahan menerima berjuta

toreh

Nanti Bah!

Kelak akan kuceritakan

Dongeng tentang rimba pada cucumu

Sebelum mimpi menyelimutinya 


\section{Kelak Bah!}

Aku akan ninabobokkan cucumu

Dengan tembang satwa yang hilang

Dan kancil kecil pulang kandang

Bah,

Pulang ya...

$$
\text { (Oleh Said Agus Salim - Balikpapan) }
$$

Walaupun masih amat belia, Agus Salim mampu memberikan penyadaran kepada banyak orang, baik kepada pemerintah daerah, pencinta lingkungan, kalangan kampus, maupun kepada masyarakat umum. Betapa tidak, melalui puisinya, dia menunjukkan bahwa kebijakan pembangunan yang selama ini dilakukan telah salah arah. Akibatnya, pembangunan bukan lagi membawa kemakmuran dan kedamaian, tetapi malah membuat kerusakan. Penggudulan hutan dan pembangunan gedung-gedung bertingkat telah mengganggu keseimbangan ekosistem. Rusaknya margasatwa, bencana banjir, dan kerusakan lingkungan yang lain merupakan dampak dari kebijakan pembangunan yang salah. Kalau gejala itu terus berlangsung, ada giris, jangan-jangan bencana yang akan tiba. Akibat jangka panjang, jangan-jangan hutan dan satwa yang ada hanyalah tinggal kenangan sehingga kelak akan kuceritakan dongeng tentang rimba pada cucumu.

Dari kandungan isi dindang dan puisi di atas kita dapat melihat bahwa sastra sarat dengan unsur-unsur yang dapat digunakan untuk membangun karakter siswa. Namun, sayang seribu sayang sastra tidak lagi akrab dengan kehidupan kita. Masyarakat telah banyak yang mencampakkan instrumen humanisasi dari kehidupannya bernama sastra. Sekolah tidak lagi memanfaatkan sastra untuk membangun karakter para siswa. Pendidikan sastra di sekolah tidak memantik siswa untuk mencintai dan menggauli sastra. Pendidikan sastra di sekolah menjadi sangat kering karena terfokus kepada pembentukan kompetensi siswa untuk sukses menjawab soal-soal dalam ujian nasional, bukan diarahkan untuk menggali nilai-nilai sebagai dasar pembentukan karakter mulia para siswa.

Kenyataan ini hendaknya mampu membangun kesadaran kita untuk mengintensifkan pendidikan sastra, terutama di persekolah kita. Pengintensifan bukan saja menyangkut penambahan alokasi waktu, tetapi perlu penataan materi, proses pendidikan, maupun sistem evaluasi yang harus diterapkan.

\section{Pendidikan Sastra yang Bagaimana yang Dapat Membangun Karakter Siswa}

Jawaban yang pasti dari pertanyaan subjudul ini adalah pendidikan sastra yang diarahkan untuk mengembangkan kompetensi bersastra para siswa. Dengan pendidikan yang demikian, para siswa akan diberi pajanan (exposur) nilai-nilai luhur dalam sastra sebagai bahan internalisasi dalam rangka membangun karakter mulia pada dirinya. Kompetensi umum bersastra itu hendaknya dijadikan rambu-rambu ketika guru merancang pendidikan sastra, baik dalam proses penyiapan bahan pendidikan, pelaksanaan pendidikan, maupun sistem evaluasi yang akan digunakan. Dalam uraian berikut dijelaskan ketiga hal tersebut.

\section{a. Penyiapan Bahan}

Terkait dengan proses penyiapan bahan pendidikan, setakat ini pendidikan sastra di persekolahan kita cenderung sangat dominatif. Gejalanya tampak pada jarangnya atau bahkan mungkin tidak pernah mendasarkan bahan pendidikan kepada hasil analisis terhadap kebutuhan atau karakteristik siswa. Materi yang disajikan di kelas merupakan hasil asumsi para pakar, perancang kurikulum, atau guru terhadap kebutuhan siswa.

Dalam pemilihan bahan pendidikan, pendidikan sastra yang humanis sepakat dengan pandangan Beach dan Marshall (1991) atau pun Nunan (1999) yang menyarankan bahwa bahan pendidikan hendaknya disesuaikan dengan kebutuhan atau pun karakteristik siswa. Bahan pendidikan tidak didasarkan kepada asumsi guru/perancang kurikulum semata. Ada keterlibatan siswa dalam menentukan materi pendidikan sastra yang akan dilaksanakan.

Karena tidak didasarkan kepada kebutuhan, keinginan, atau karakteristik siswa, materi pendidikan sastra di sekolah cenderung membosankan. Gejala tersebut tidak selaras dengan perspektif konstruktivis yang menyatakan bahwa pendidikan akan efektif jika materi pendidikan yang dipilih terkait dengan pengetahuan yang telah dimiliki siswa. Keterkaitan itu akan membangkitkan skemata siswa terhadap materi pendidikan yang akan diperolehnya.

Terkait dengan proses analisis kebutuhan, ada saran para pakar yang layak diperhatikan. Retchterich dan Chancerel (dalam Nunan, 1999) membagi kebutuhan atas dua jenis, yakni kebutuhan objektif dan kebutuhan subjektif. Kebutuhan objektif adalah kebutuhan yang dapat didiagnosis oleh guru berdasarkan analisis terhadap data pribadi siswa, kecakapan sastra mereka, dan pola-pola penggunaan sastra . Nunan (1999) lebih suka memilah kebutuhan siswa atas dua jenis, yakni kebutuhan isi dan kebutuhan proses. Kebutuhan isi mencakup pemilihan dan pengurutan bahan pendidikan -- yang secara tradisional merupakan bidang rancangan silabus -- sedangkan kebutuhan proses mengacu kepada seleksi dan pengurutan tugas-tugas belajar dan pengalaman -- yang secara tradisional dilihat sebagai bidang metodologi. Di samping itu, Nunan (ibid) membedakan analisis kebutuhan awal dan analisis kebutuhan yang sedang berlangsung. Analisis kebutuhan awal dilakukan sebelum pendidikan dimulai. Analisis kebutuhan yang sedang berlangsung merujuk pada analisis yang secara relatif sering bersifat informal dan dilaksanakan guru begitu pendidikan telah dimulai.

Analisis terhadap kebutuhan siswa dapat dilakukan dengan menggunakan angket yang berisi butir-butir sikap siswa, pengalaman belajar sebelumnya, kemampuan-kemampuan awal yang telah dimiliki, dan kemampuankemampuan apa yang ingin dicapai. Hasil analisis ini dipadu dengan fakta khazanah sastra Indonesia atau daerah di masyarakat sehingga materi pendidikan benar-benar menjadi materi yang kontekstual.

Materi pendidikan yang didasarkan kepada kebutuhan atau karakteristik siswa paling tidak mempunyai tiga manfaat. Pertama, materi tersebut menjadikan pendidikan lebih bermakna. Apa yang kita ajarkan di kelas memang hal 
yang benar-benar dibutuhkan siswa, bukan sesuatu yang mubazir karena siswa tidak membutuhkannya. Ada beberapa penyebab hal itu terjadi, antara lain karena siswa telah menguasai materi itu, atau mungkin memang dirasa tidak bermanfaat bagi mereka. Materi pendidikan yang bermakna sejauh mungkin menghindari kemubaziran, menghindari pemborosan waktu dan tenaga.

Kedua, materi yang didasarkan kepada kebutuhan siswa dapat membangkitkan motivasi siswa dalam mengikuti proses pendidikan. Dalam kajian psikologi belajar terungkap bahwa siswa akan merasa senang mempelajari sesuatu yang memang mereka butuhkan. Dengan demikian, pemenuhan kebutuhan mereka merupakan alternatif cara untuk membangkitkan motivasi mereka dalam mengikuti proses pendidikan. Dalam konteks ini, berbagai keluhan yang sering dilontarkan terhadap rendahnya motivasi siswa dalam mengikuti pendidikan sastra selama ini mungkin dapat diminimalisasi dengan menggalakkan pendidikan sastra yang didasarkan kepada kebutuhan siswa.

Ketiga, pendidikan yang didasarkan kepada kebutuhan siswa mempunyai manfaat yang dalam istilah pendidikan disebut dampak pengiring. Membiasakan pendidikan dengan mempertimbangkan kebutuhan siswa secara tidak langsung akan memberi contoh kepada mereka hidup humanis. Mereka diberi contoh sikap untuk menghargai keinginan orang lain, tidak memaksakan kehendak manakala dihadapkan kepada keinginan orang banyak. Dampak pengiring semacam ini sering dilupakan dalam proses pendidikan di negeri ini. Oleh karena itu, wajar jika produk pendidikannya menghasilkan manusia-manusia yang cenderung otoriter yang sulit menghargai pendapat dan hak-hak orang lain, sulit menerimana kerberagaman.

\section{b. Pelaksanaan Proses Pendidikan}

Membangun kompetensi sastra daerah para siswa bukanlah pekerjaan semudah mengerdipkan kelompok mata. Pencapaiannya memerlukan proses pendidikan yang menempatkan siswa sebagai pihak yang aktif dalam membaca dan merespon sastra. Terkait dengan hal ini, Rodger (1983) menyatakan bahwa siswa tidak akan pernah belajar untuk memahami sastra jika dirinya kurang membaca sastra. Mereka juga tidak akan pernah memperoleh keterampilan bersastra jika kelas pasif. Tujuan utama pendidikan sastra adalah mengajari siswa menemukan signifikansi makna sastra di dalam dirinya melalui berbagai tindakan membaca sastra. Hal ini dapat dilakukan melalui metode yang memungkinkan mereka meramalkan atau menilai, yakni menerapkan prinsip-prinsip dan prosedur membaca sastra dan melaporkan hasilnya.

Ada berbagai model pendidikan sastra yang dapat digunakan. Salah satu model yang cocok untuk mencapai tujuan pendidikan sastra tersebut adalah model respon. Dalam pendidikan sastra model ini, siswa diarahkan untuk membaca atau mendengarkan sastra sebanyak-banyaknya dan memberikan respon terhadap sastra yang didengar atau dibacanya, baik dalam bentuk lisan maupun tulisan.

Dalam proses pendidikan, respon sastra tersebut dapat ditandai oleh beberapa aktivitas, antara lain: (a) terlibat, dalam arti terlibat empati dalam teks sastra; (b) mendeskripsikan, dalam arti menempatkan dan memproduksi kembali informasi yang ada dalam teks sastra; (c) memikirkan, yakni memikirkan unsur-unsur sastra, seperti karakter, latar, bahasa dalam teks sastra sehingga mampu membuat pernyataan-pernyataan tentang maknanya; (d) menjelaskan, yakni menjelaskan unsur-unsur dalam teks sastra; (e) menghubungkan, yakni mengaitkan pengalamannya dengan bahan-bahan dalam teks sastra; (f) menafsirkan, dalam arti menunjukkan reaksi, deskripsi, konsepsi, dan hubungan-hubungan yang dapat dibuat untuk mengatakan dengan jelas tema sastra; dan ( $\mathrm{g}$ ) menyimpulkan, yakni menyimpulkan isi dan kualitas teks sastra (lihat Beach dan Mashall, 1991).

Dalam proses pendidikan, guru dapat menggunakan salah satu atau kombinasi strategi respon sebagaimana ditawarkan oleh Beach dan Marshall (1991) berikut ini.

(a) Mengungkapkan pikiran secara nyaring. Aktivitas ini dapat digunakan untuk mendeskripsikan reaksi-reaksi siswa, keraguan, prediksi, pertanyaan, hipotesis, penafsiran, dan simpulan. Instrumen ini lebih cocok digunakan untuk mengungkapkan respon terhadap segmen-segmen pendek teks sastra, seperti baris atau paragraf.

(b) Menceritakan kembali. Dalam aktivitas respon ini, siswa merangkum atau mengabstrasikan kembali apa yang terjadi dalam teks sastra. Kegiatan menceriterakan kembali membantu siswa belajar banyak melalui peristiwaperistiwa yang relevan, relatif, yang dapat digunakan untuk memahami sudut pandang teks sastra.

(c) Menulis bebas. Menulis bebas digunakan siswa untuk menuliskan pikiran-pikirannya di dalam keterbukaan, secara spontan tanpa perhatian untuk mengorganisasi, mengedit - sekadar ekspresi spotan secara tertulis terhadap apa yang mereka pikirkan terkait dengan sastra yang mereka baca/dengar.

(d) Membaca jurnal. Dalam membaca teks jurnal, siswa merespon, mereaksi, dan memikirkan ide-ide sebagaimana terjadi selama membaca teks dalam jurnal sastra.

(e) Belajar mencatat ke dalam buku harian. Ketika memberi respon kepada teks sastra, secara terus-menerus siswa mempelajari strategi dan ide-ide baru untuk memahami teks itu. Dalam proses tersebut, siswa memadukan ideide dan stategi baru itu ke dalam pengetahuan yang telah mereka miliki, memodifikasi pengetahuan itu untuk memperkirakan pengetahuan baru mereka. Dalam konteks itu, belajar mencatat ke dalam buku harian dapat membantu siswa mengintegrasikan pengetahuan baru ke dalam pengetahuan yang ada.

(f) Memperkaya kartu katalog atau bank data tentang konsep-konsep sastra. Ketika mereka membaca sastra, mereka secara cepat memperoleh gudang pengetahuan tentang pengarang, jendre sastra, tipe-tipe karakter, jalan cerita, latar, tema, dan teknik. Siswa dapat merekamnya dalam kartu katalog atau dalam file komputer.

(g) Bertanya-menanyakan. Ketika memahami hal-hal dalam teks sastra, siswa membangun frem untuk membimbing pengetahuannya dalam proses penemuan. Ketika itu, siswa dapat mengajukan pertanyaan secara bebas. Pertanyaan-pertanyaan itu didaftar di papan tulis. Kemudian, guru membimbing siswa untuk mendiskusikan pertanyaan-pertanyaan itu. 
(h) Mendaftar. Dalam mendaftar ini, siswa mengembangkan butir-butir tipe yang sejenis, misalnya tindakantindakan, karakter tokoh, atau imajinasi puisi. Selanjutnya, butir-butir itu didaftar berdasarkan urutan tertentu.

(i) Daftar pararel. Untuk mendorong siswa mendapatkan pemahaman tentang hubungan daftar informasi, guru dapat menggunakan daftar pararel, yang menempatkan bagian demi bagian.

(j) Pemetaan. Dalam pemetaan, secara fisual siswa memotret hubungan-hubungan dalam teks sastra dengan menggunakan model jaring laba-laba atau diagram pohon. Jaring hubungan itu digunakan untuk merepresentasikan kaitan-kaitan antara karakter, peristiwa-peristiwa, tempat, atau ide-ide.

(k) Membuat diagram venn. Siswa juga dapat menggunakan diagram venn untuk membedakan dan membandingkan karakter, latar, dan ide-ide dalam sastra.

(1) Membuat grafik. Dalam membaca atau mendengarkan teks sastra, para siswa menemukan perkembangan cerita, karakter, kekuasaan, kepercayaan diri, atau sifat-sifat yang dapat diungkapkan dalam bentuk grafik.

(m) Skala sikap. Skala sikap dapat digunakan untuk menentukan sikap-sikap terhadap fenomena sastra.

(n) Pementasan cerita. Dalam membuat pementasan cerita, siswa menyajikan serangkaian peristiwa dari sebuah teks sastra ke dalam naskah berdasarkan peristiwa-peristiwa. Dia mengubah peristiwa-peristiwa tersebut ke dalam naskah.

(o) Penarfsiran lisan. Dalam penafsiran lisan terhadap sebuah teks sastra, siswa membaca nyaring sebuah teks dalam kelompok besar atau kelompok kecil sebagai sebuah alat untuk menyampaikan penafsirannya terhadap sebuah teks.

(p) Menuliskan kembali, merevisi, menambahkan dalam teks sastra. Dalam aktivitas respon ini, siswa dapat mengakhiri, menambah episode, merevisi peristiwa, alternatif gaya, tempat, karakter, atau membuat dialog.

(q) Bermain peran. Dalam aktivitas respon ini, siswa dapat mengadopsi peran, karakter, atau memfokuskan pada satu dilema atau situasi dalam teks sastra.

(r) Mereview buku sastra. Para siswa dapat menulis review buku dengan cara merangkum buku sastra itu, kemudian menyimpulkannya .

Dari berbagai strategi respon tersebut tampak bahwa siswa ditempatkan sebagai individu yang aktif. Pendidikan sastra tidak lagi bersifat transfer, tetapi generatif. Terkait dengan hal ini, Slavin (2000) menyatakan bahwa salah satu prinsip paling penting dari psikologi pendidikan adalah guru tidak dapat hanya semata-mata memberikan pengetahuan kepada siswa. Siswa harus membangun pengetahuan di dalam benaknya sendiri. Guru dapat membantu proses ini dengan cara-cara mengajar yang membuat informasi sangat bermakna dan sangat relevan bagi siswa, dan memberi kesempatan kepada siswa untuk menemukan atau menerapkan ide-ide diri dan dengan mengajak siswa agar menyadari dan secara sadar menggunakan strategi-strategi mereka untuk belajar. Secara metaforis dapat dikatakan bahwa guru dapat memberi tangga untuk dapat membantu siswa mencapai tingkat pemahaman yang lebih tinggi. Dalam pelaksanaannya, harus diupayakan agar siswa sendiri yang memanjat tangga tersebut.

Uraian di atas mengisyaratkan bahwa pendidikan sastra di kelas selayaknya tidak bersifat dominatif. Secara humanis siswa diantarkan untuk mencapai kompetensi sastra yang diidealkan. Sistem pendidikan semacam ini sering disebut pendidikan yang terpusat pada siswa (student-centered instruction). Di dalam kelas yang terpusat pada siswa, peran guru adalah membantu siswa mengembangkan kompetensi kesastraannya, bukan memberikan ceramah atau mengendalikan seluruh kegiatan kelas. Dalam konteks ini, guru harus mengupayakan agar siswa secara aktif belajar, baik melalui interaksi dengan guru, bahan ajar, lingkungan, teman sekelas, atau yang lain.

Keberhasilan pendidikan yang berpusat pada siswa ditentukan oleh banyak faktor, salah satu di antaranya adalah faktor metode pendidikan yang digunakan. Metode pendidikan yang digunakan selayaknya adalah yang memberi peluang kepada siswa sebanyak-banyak untuk secara aktif terlibat dalam proses pendidikan. Untuk mengembangkan kompetensi sastra daerah para siswa, guru dapat menggunakan metode kooperatif. Di samping memecahkan masalah dalam kelompok kecil mereka, siswa belajar prinsip demokrasi melalui interaksi hari ke hari satu sama lain. Hal ini dapat tercipta karena dalam pendidikan kooperatif terdapat saling ketergantungan positif, terjadin interaksi tatap muka, adanya akuntabilitas individu, dan keterampilan untuk menjalin hubungan antarpribadi atau keterampilan sosial yang secara sengaja diajarkan.

Ada bebeberapa metode pendidikan kooperatif yang dapat diterapkan dalam pendidikan sastra, antara lain metode STAD (Student Teams Achievement Division); metode jigsaw, metode GI (Group Iinvestigation), dan metode struktural (yang mencakup metode Thing-Pair-Share dan metode Numbered Head Together). Penggunaan masingmasing metode tersebut harus disesuaikan dengan karakterisitik dan kompetensi dasar yang ingin dicapai, materi pendidikan, karakteristik siswa, dan sarana pendidikan.

Pendidikan kooperatif selaras dengan paradigma pendidikan konstruktivis. Ide-ide konstruktivis modern banyak berlandaskan pada teori Vygotsky, yang telah digunakan untuk menunjang medode pendidikan yang menekankan pada pendidikan kooperatif. Prinsip kunci yang diturunkan dari teorinya telah memegang peranan penting. Penekanannya adalah hakikat sosial pendidikan. Ia menyatakan bahwa siswa belajar melalui interaksi dengan orang dewasa dan teman sebaya yang lebih mampu. Pada pendidikan kooperatif siswa dihadapkan pada proses berpikir teman sebaya mereka; metode ini tidak hanya membuat hasil belajar terbuka untuk seluruh siswa, tetapi juga membuat proses berpikir siswa lain terbuka untuk seluruh siswa (periksa Slavin, 2000).

Menurut Ibrahim dkk. (2000), unsur-unsur dasar pendidikan kooperatif adalah sebagai berikut: (a) siswa dalam kelompoknya haruslah beranggapan bahwa mereka "sehidup sepenanggungan bersama.", (b) siswa bertanggung jawab atas segala sesuatu di dalam kelompoknya, seperti miliknya sendiri, (c) siswa haruslah melihat bahwa semua anggota di dalam kelompoknya memiliki tujuan yang sama, (d) siswa harus membagi tugas dan tanggung jawab yang sama di antara anggota kelompoknya, (e) siswa akan dikenai penilaian atau diberikan hadiah/penghargaan yang juga akan dikenakan untuk semua anggota kelompok, (f) siswa berbagi kepemimpinan dan 
mereka membutuhkan keterampilan untuk belajar bersama selama proses belajarnya, dan (g) siswa akan diminta mempertanggungjawabkan secara individual materi yang ditangani dalam kelompok kooperatif.

Kalau kita perhatikan, pendidikan kooperatif mempunyai sejumlah keunggulan. Keunggulan tersebut tentu saja bila dikaitkan dengan metode yang lain. Menurut Ibrahim dkk. (ibid) paling tidak pendidikan kooperatif mempunyai tiga keunggulan, yakni keunggunlan yang terkait dengan hasil belajar akademik, penerimaan terhadap perbedaan individu, dan pengembangan keterampilan sosial.

Terkait dengan hasil belajar, pendidikan kooperatif meningkatkan kinerja siswa dalam tugas-tugas akademik. Beberapa ahli berpendapat bahwa model ini unggul dalam membantu siswa memahami konsep-konsep yang sulit. Para pengembang model ini telah menunjukkan bahwa model struktur penghargaan kooperatif telah meningkatkan penilaian siswa pada belajar akademik dan perubahan norma yang berhubungan dengan hasil belajar.

Keunggulan kedua dari pembelajarn kooperatif adalah penerimaan yang luas terhadap orang yang berbeda menurut ras, budaya, kelas sosial, kemampuan, dan ketidakmampuan. Goldon dan Allport (dalam Ibrahim dkk, 2000) mengajukan premis bahwa hanya kontak fisik saja di antara orang-orang yang berbeda ras atau kelompok etnik tidak cukup untuk mengurangi kecurigaan dan perbedaan ide. Pendidikan kooperatif memberi peluang kepada siswa yang berbeda latar belakang dan kondisi untuk bekerja saling bergantung satu sama lain atas tugas-tugas bersama, dan melalui penggunaan struktur penghargaan kooperatif, belajar untuk menghargai satu sama lain. Dengan demikian, pendidikan kooperatif merupakan sarana yang efektif untuk mendidik perilaku humanis siswa. Jika premis ini dipegang, tampaknya pendidikan sastra secara makro dapat menyumpang bagi pencegahan terjadinya pertumpahan darah akibat konflik etnis dan kepentingan di negeri ini.

Selain itu, pendidikan kooperatif unggul dalam mengembangkan keterampilan sosial melalui kerja sama dan kolaborasi. Keterampilan ini amat penting untuk dimiliki di masyarakat yang secara sosial manusia saling membutuhkan dan bekerja sama. Namun sayang, ketempilan ini tidak banyak dikembangkan dalam pendidikan sastra. Padahal, jika keunggulan ini dapat diraih, mungkin pertikaian kecil antarpelajar dan bentuk-bentuk pertikaian yang lain dapat dihindari.

\section{c. Proses Penilaian}

Dalam proses pendidikan, termasuk dalam pendidikan sastra, penilaian bukanlah istilah asing. Paling tidak, pada akhir suatu program pendidikan biasanya dilakukan penilaian. Ada berbagai jenis penilaian. Masing-masing jenis itu mempunyai fungsi tertentu. Jika dikaitkan dengan pelaksanaan proses pendidikan, penilaian dapat difungsikan untuk melihat pencapaian hasil belajar atau efektivitas pelaksanaan proses pendidikan (Harsiati, 2017; Fawzi, 2016).

Dalam proses pendidikan sastra, penilaian dapat dipilah menjadi dua, yakni penilaian yang mengarah pada produk dan penilaian yang mengarah kepada proses (periksa Nunan, 1999). Penilaian yang mengarah kepada produk cenderung melihat pencapaian hasil belajar pada hasil akhir, yang biasanya dilakukan melalui instrumen tes; sedangkan penilaian yang mengarah kepada proses melihat pencapaian hasil belajar bukan semata-mata dari hasil akhir, tetapi juga dari proses pencapaiannya.

Pada umumnya, penilaian proses pendidikan sastra di persekolahan kita cenderung mengarah kepada penilaian produk, sedikit sekali mengarah kepada penilaian proses. Penilaian yang dikembangkan dengan sistem ini jelas dominatif, kurang menghargai proses belajar. "Nasib" anak cenderung divonis dari performansi akhir, tanpa dilihat bagaimana usaha mereka.

Pada hakikatnya penilaian bukan hanya dilakukan sesaat, akan tetapi harus dilakukan secara berkala dan berkesinambungan. Di samping itu, penilaian bukan hanya menaksir suatu pencapaian secara parsial, melainkan harus menaksir sesuatu dengan cara menyeluruh yang meliputi proses dan hasil pertumbuhan dan perkembangan wawasan pengetahuan, sikap, dan keterampilan apresiasi sastra yang dicapai siswa. Oleh karena itu, untuk menetapkan seseorang tidak mencapai target yang dituntut bukan hanya dari hasil sesaat, misalnya diambil dari nilai ujian akhir. Bisa saja terjadi seseorang yang dalam proses performansinya bagus, tetapi karena kesehatannya kurang baik, pada saat ujian dia akan mendapatkan nilai kurang bagus. Rasanya tidak tepat memvonis siswa tidak naik kelas gara-gara gagal dalam ujian akhir, padahal dalam keseharian prestasinya amat baik.

Dalam perpektif pendidikan sastra yang humanis, penilaian berfungsi sebagai respon guru terhadap responrespon siswa. Oleh karena itu, paling tidak, ada tiga tujuan yang hendak dicapai dari proses penilaian, yakni: (a) untuk menyiapkan deskripsi siswa tentang apa yang mereka lakukan ketika mereka merespon sastra; (b) untuk menyiapkan "cetak biru" pengembangan potensi siswa; dan (c) untuk membantu siswa belajar menilai diri sendiri (lihat Beach dan Marshall, 1991).

Dalam sistem pendidikan sastra yang humanis, penilaian hasil belajar siswa tidak hanya ditentukan oleh hasil akhir, tetapi juga oleh proses (bandingkan dengan Nunan, 1999). Sistem penilaian yang demikian biasanya disebut authentic assessment. Dalam sistem penilaian ini, proses penilaian dilakukan selama dan sesudah proses pendidikan berlangsung; penilaian dapat digunakan guru untuk formatif dan sumatif; yang diukur adalah keterampilan dan performansi, bukan mengingat fakta; sifatnya berkesinambungan; terintegrasi; dan dapat digunakan sebagai umpan balik (lihat Nurhadi dkk., 2004:53).

Jika dikaitkan dengan pendapat Hill dkk. (1998), penilaian sebaiknya ditekankan pada penilaian proses, dengan penggunaan penilaian portofolio. Hasil pencapaian belajar direkam dari berbagai instrumen, misalnya catatan guru, anekdot, jurnal, informasi dari orang tua, di samping produk akhir performansi siswa.

Jika digunakan secara tepat, penilaian portofolio mempunyai sejumlah kelebihan. Barton dan Collins (1997) mendeskripsikan kelebihan-kelebihan itu sebagai berikut.

a. Portofolio memberikan kesempatan kepada guru atau siswa untuk mengkomunikasikan hasil pendidikan setelah atau pada saat proses pembelejaran di kelas berlangsung. 
b. Portofolio memungkinkan guru untuk melihat hasil kerja siswa sesuai dengan konteksnya. Portofolio menampilkan struktur untuk masing-masing bagian dan bukti isinya. Struktur ini memungkinkan guru untuk melihat bagaimana masing-masing bagian belajar siswa untuk diselaraskan ke dalam gambaran besar dari rencana pendidikan yang telah disusun oleh guru.

c. Portofolio akan merangsang sebuah perubahan di dalam hak belajar pada masing-masing siswa. Siswa akan belajar bagaimana membuat keputusan tentang kualitas dan kebermanfaatan dari kerja mereka masing-masing, dan keputusan itu dapat menuntun kepada sebuah makna yang kuat dari penyelesaian secara personal.

d. Portofolio akan membantu guru membuat sebuah forum siswa untuk mengkomunikasikan ide-ide mereka di dalam suatu lingkungan yang mendukung. Interaksi-interaksi ini akan membantu siswa dalam penampakan dirinya.

e. Portofolio akan dapat membantu kita menjadi guru yang lebih baik. Proses portofolio akan mendorong guru untuk memperhatikan secara konstan apa yang senyatanya ingin diselesaikan oleh siswa kita. Ini merupakan tantangan bagi guru untuk mencoba cara-cara baru merancang berbagai pencapaian ini.

Penilaian portofolio didasarkan pada indikator pencapaian belajar dari sejumlah catatan atau dokumen. Menurut Budimansyah (2002), penilaian portofolio bisa didasarkan pada catatan atau dokumen: (a) hasil ulangan harian dan ulangan umum yang biasanya dicatat dalam buku nilai siswa, (b) tugas-tugas terstruktur biasanya dikumpulkan oleh guru dan disimpan dalam sebuah map khusus untuk tugas-tugas siswa, (c) catatan perilaku harian para siswa biasanya tersimpan pada buku khusus yang disebut catatan anekdot, dan (d) laporan kegiatan siswa di luar sekolah yang menunjang kegiatan belajar, bisanya dikumpulkan guru dan selanjutnya didokumentasikan.

\section{Penutup}

Gejala terjadinya krisis moral di negeri ini sudah berada pada ambang yang mengkhawatirkan. Kita yang berkecimpung di dunia pendidikan tentu saja tidak bisa berpangku tangan. Kita perlu segera melakukan reformasi pendidikan sebagaimana dilakukan negeri Cina, yakni menekankan pendidikan karakter pada para siswa, mulai dari satuan pendidikan prasekolah hingga perguruan tinggi.

Pendidikan karakter perlu ditautkan pada semua bidang studi, termasuk dalam pendidikan sastra. Dilihat dari substansi materinya, pendidikan sastra mempunyai peran strategis untuk membangun karakter siswa.

Agar mampu berperan dalam membangun karakter siswa, pendidikan sastra perlu dirancang secara baik, menyangkut pemilihan materi, proses pendidikan, dan proses evaluasi. Materi pendidikan hendaknya bersifat kontekstual. Dalam khazanah sastra daerah dan sastra Indonesia tumbuh subur bahan dasar untuk menyemai karakter positif para siswa. Bahan ajar itu akan bisa diinternalisasi siswa bila proses pendidikannya mampu membawa siswa mencintai dan menggauli sastra. Pendidikan sastra model respon merupakan satu pendekatan pembelajaran sastra layak diterapkan. Sementara itu, proses evaluasi dalam pendidikan sastra hendaknya menekankan proses daripada hasil dengan memanfaatkan instrumen penilaian portofolio.

\section{DAFTAR RUJUKAN}

Aminuddin. (1984). Pengantar Memahami Unsur-unsur dalam Karya Sastra. Malang: IKIP Malang.

Budimansyah, D. (2002). Model Pembelajaran dan Penilaian Portofolio. Bandung: Ganesindo.

Barton, J. dan Coolins, A. (1997). Portfolio Assessment: A Handbook for Educators. Parsippany: Dale Seymaour Publications.

Beach, R. W. dan Marshall, J. D. (1991). Teaching Literature in the Secondary School. San Deigo: Harcourt Brance Jovanovich, Publishers.

Borba, M. (2001). Building Moral Intelligence. Sanfrancisco: Jossey-Bass.

Fawzi, A. (2016). Pengembangan Alat Penilaian Pembelajaran Menyimak Eksposisi Kelas X SMA. Jurnal Bahasa dan Seni, Volume 44 Nomor 2 2017, pp 125-134

Harsiati, T. (2017). Feedback And Self Regulation In Writing Learning Assesment In Junior High School. ISLLAC : Journal of Intensive Studies on Language, Literature, Art, and Culture, Volume 1 Number 1 2017, pp 71-78, http://dx.doi.org/10.17977/um006v1i12017p071.

Hill, B. C. dkk. (1998). Classroom Based Assesment. Norwood, Massachusetts: Christopher-Gordon Publishers, Inc.

Ibrahim, M, dkk. (2000). Pembelajaran Kooperatif. Surabaya: Unesa Press.

Komalasari, K. (2013). Pendidikan Karakter di Persekolahan Kita. Dalam Budimansyah, Dasim dan Komalasari, Kokom (Eds.). Pendidikan Karakter: Nilai-Inti bagi Upaya Pembinaan Kepribadian Bangsa. Bandung: Widya Aksara Press.

Lickona, T. (1991). Educating for Character. New York: Bantam Books.

Nunan, D. (1999). Second Language Teaching and Learning. Boston: Heinle and Heinle Publishers.

Nurhadi dkk. (2004). Pembelajaran Kontekstual dan Penerapannya dalam KBK. Malang: Penerbit Universitas Negeri Malang.

Rodger, A. (1983). Langage for Literature dalam C. J. Brumfit (Ed.). Teaching Literature Overseas Language-Based Approaches. Oxford: Pergamon Press.

Sauri, S. (2013). Strategi dan Implementasi Pendidikan Karakter Bangsa. Dalam Budimansyah, Dasim dan Komalasari, Kokom (Eds.). Pendidikan Karakter: Nilai Inti bagi Upaya Pembinaan Kepribadian Bangsa. Bandung: Widya Aksara Press.

Slavin, R. (2000). Educational Psychology: Theory and Practice. Boston: Allyn and Bacon, Inc.

Teeuw, A. (1982). Khazanah Sastra Indonesia. Jakarta: PN Balai Pustaka. 